\title{
과테말라 기술교육훈련원 건립사업 사후평가
}

주 인 중 , 김 상 진 / 한국직업능력개발원 박사

\section{I . 평가 배경 및 목적}

$\mathrm{KOICA}$ 의 직업훈련시원 사업은 개발도상국의 현실을 고려할 때 경제발전을 견인 할 수 있는 가장 중요한 요 소인 기능인력을 양성할 수 있는 인프라를 제공한다는 점에서 매우 중요한 의의를 지닌다.

본 사후 펑가는 한 · 과테말라 직업훈련원 지원 사업 종료 후 그 간의 건립 및 운영을 지원한 과테밀라 직원 훈련원의 운영실태, 훈련현황, 지원 장비 밎 기자재 활 용정도 등을 사업 계획과 비교하여 목표 달성 여부, 그 간의 사업효과 측정, 시속 가능성 혹은 사립발전성 평 기를 위해 수행하는 것이다.

동 평가 걸과를 면밀하게 검토하여 보다 효율적인 지 원의 기초사료로 활용하고 사업의 문제점 분석, 원인 파악 및 대책 강구를 동해 직업훈련지원 사업 전반에 대한 기선인과 정칙적 시사점을 도출힌다. 그리고 디
나아가, 이 사업을 통한 교훈과 성과를 파악하여 여타 수원궁을 대상으로 추진 혹은 계획 중인 직업훈련 사 업에 이빈 평가 결과를 반영함으로써 한국국제협력단 직업훈련 지원사업의 내신화 및 질적 개선, 나아가 협 력 호과를 지속적으로 증대할 수 있을 것이다.

II. 사업개요

\section{1. 사업배경}

과테만라 정부는 기순변화에 적응할 수 있는 숙련된 기술인려 양성과 기존 기술인력의 능력 강화 교육을 통 한 기술수준의 향상이 지역사회와국가 경제발전의 는 간인을 인식하고 기술교육 및 직업훈련에 내한 수요에 효과적으로 대처하기 위해 지방별 특성을 고려한 숙련 기술인려 앙성과 재교육을 위한 직업훈련 지방거점을 구촉해 나갈 계획을 가지고 있었다. 특히 과테말라 정 
부는 우리 정부의 지원으로 93 99년간 설립되어 성공 적으로 운영되고 있는 3 개 직업훈련원을 높이 평가하 여, INTECAP(직업훈련 및 생산성기술연구원)을 통해 과테말라시 동붑부에 위치한 교통의 요지인 Zacapap 주에 기술교육훈련원 긴립 지원을 요청해왔다.

2000년 과테말라 대통령 취임식에서 특사로 파견된 양성철 의원과 개별면담을 통해 동 사업 지원을 요청 하였고 2002년 KOICA 후보사업으로 선정하여 사전 조사단을 파견하였다. 2003 년 실시협의단을 파견, 구 상서를 체결, 2004 년 건축기공식을 개최하여 2005년 에 개원하였다.

\section{2. 사업목표}

상위목표(Overall goal)로는 기술교육훈련 원 설립으로 우수한 기능인력 양성 및 공급을 통하여 지역사회와 국가경제 발전에 기여하는 것이다. 프로젝트 목표 (Project goal)는 미취업 청소년들과 취약계층 근로사 들에게 직업능릭개발 기회를 제공함으로써 취업기회 를 확대하고 이를 통해 안징적 생활기반 마련과 지역 사회 및 국가 발전에 기여하는 것이다. 이를 위해 4기 공과를 설치, 직업훈련 운영체계 구촉, 우수 훈련 시설 및 장비, 기자재 확보, 훈련교사 양성 및 연수, 훈련 교 재와 교과과정 개빌 등을 지원한다.

\section{3. 사업 내용}

〈표 1) 우리정부의 ODA지원 실적

단위 : 박만 단거, 순 지출 기준)

\begin{tabular}{|c|c|c|c|}
\hline 국 명 & 과테말라 & 분 야 & 직업 훈련 \\
\hline 1.사 업명 & $\begin{array}{l}\text { - 국문: 과테말라 기술교육훈 } \\
\text { - The Project for Establishm }\end{array}$ & temak & hnical Education and Training | nssitutue \\
\hline $\begin{array}{l}\text { 2. 사업기간 및 } \\
\text { 사업비(USD) }\end{array}$ & -2003-2004(2년)/1·8.6 & & \\
\hline 3. 사업 지역 & - 과테말라 Zacapa 시 소재 & 연원 & \\
\hline 4. 개발목표 & - 과테말라 정부의 기술인력 & 여 경저 & 및 인적자원개발 \\
\hline 5. 사업 목표 & $\begin{array}{l}\text { - Zacapa 시에기술교육훈흔 } \\
\text { 지원하고 지역사회와 국가 }\end{array}$ & $\begin{array}{l}\text { 차정ㅂ } \\
\text { 른물론 }\end{array}$ & $\begin{array}{l}\text { 덥, 제과제빵, 이미용 등의 공과를 개 설하여 기술인력 양성을 } \\
\text { 거점 구축을 위한 기반 마련 }\end{array}$ \\
\hline 6. 수혜대 상자 & \multicolumn{3}{|c|}{ - 과테말라 Zacapa 주 인근지멱 주민 및 화생 } \\
\hline \multirow{3}{*}{ 7.투 입 } & \multicolumn{2}{|c|}{ 수원국 측 } & 아 측 \\
\hline & $\begin{array}{l}\text { - 훈련원 부지 제공 } \\
\text { - 훈련원 설계 및 시공감리 } \\
\text { - 주차장 등 부대시설 건축 } \\
\text { - 인프라 구축 } \\
\text { - 기자재 통관비용 부담 } \\
\text { - 파견인력 편의 제공 }\end{array}$ & & $\begin{array}{l}\text { - 시설 건축: } 56 \text {. 만 달러 } \\
\text { - CM 용멱비(6. 만 달러) 포함 } \\
\text { - 기지재 : 48만 달러 } \\
\text { - 연수상: } 11.8 \text { 만 달러 } \\
\text {-PMC 용역비(6.8만 달러)포함 } \\
\text { - 기타겸비: } 2.7 \text { 만 달러 }\end{array}$ \\
\hline & 합계: 10만 달러 & & 합계: 118.6 만 달러 \\
\hline
\end{tabular}




\begin{tabular}{|c|c|c|c|}
\hline 국 몀 & 과테 말라 & 분 야 & 죅업 \\
\hline 8. 섬 과 & \multicolumn{3}{|c|}{$\begin{array}{l}\text { - 기술교육 및 직업교육에 의한 고용기회 확대 } \\
\text { - 공업기술인력 양섬을 동한 지역산업체 겸잼력 제고 } \\
\text { - 우수 국산기자재 제 공 및 기술이전으로 중미지멱 협력확대 기반조섬 및 한국 업체 측면지원 }\end{array}$} \\
\hline $\begin{array}{l}\text { 9. 원조총 괄기관 } \\
\text { (수원국) }\end{array}$ & \multicolumn{3}{|c|}{$\begin{array}{l}\text { - 겸제기획원 } \\
\text { (Secretaria de Planificacion y Programacion/SEGEPLAN) }\end{array}$} \\
\hline $\begin{array}{l}\text { 10. 사업실시기관 } \\
\text { (수원국) }\end{array}$ & \multicolumn{3}{|c|}{$\begin{array}{l}\text { - 직업훈련공단 } \\
\text { (Instituto Tecnico de Caoacitacion y rocuctividad/NTECAP) }\end{array}$} \\
\hline
\end{tabular}

\section{4. 평가 방법}

$\mathrm{KOICA}$ 사업평가 가이드라인에 의거 5 개 항목을 중심 으로 평가했다. 이빈 평가에는 설문조사, 심층면담, 현 지 방문 관찬, 기타 관련 자료 수집 등의 방법을 횔용
힜다. 그리고 기존의 세부 평가항목에 더하여 최근 개 선된 펑가지표를 반영하였다. 사후평가임을 고려하여 목표달성도와 더불어 사업츳진의 효율성, 효과성, 시 속가능성 등에 초전을 두어 평가를 실시했다.

\section{5. 평가 항목}

\begin{tabular}{|c|c|}
\hline 항 목 & 세브 평가 지표 \\
\hline $\begin{array}{l}\text { 타당성 } \\
\text { (Rationate) }\end{array}$ & $\begin{array}{l}\text { - 현지 수요(needs) 파 악의 충분성 } \\
\text { - 사업 대 상지 선정의 타당성 }\end{array}$ \\
\hline $\begin{array}{l}0 \text { 효과성 } \\
\text { (Etectiveness) }\end{array}$ & $\begin{array}{l}\text { - 공과 설치 및 운영 현황(훈련생 수) } \\
\text { - 훈련교사의 역량양ㅇㅂㅣ 운용 능력) } \\
\text { - 기자재 활용도 }\end{array}$ \\
\hline $\begin{array}{l}\text { 효율성 } \\
\text { (Eficiency) }\end{array}$ & $\begin{array}{ll}\text { - 사업추진 일정 } & \text { - 협력 규모의 적정성 } \\
\text { - 주요투입요소의 적절성 (사업규모, 기자재, 파견, 연수 등) } \\
\text { - 사업수행 체계의 효율섬 } & \text { - 지원체계의 효율섬, 타 협력수단과의 연계섬 }\end{array}$ \\
\hline $\begin{array}{l}O \text { 파급효과 } \\
\text { (Impad) }\end{array}$ & $\begin{array}{l}\text { - 지멱, 계층별 수혜자 범위 및 수혜층에 대한 효과 } \\
\text { - 과테말라 직 업훈련제도에 미친 명향 및 기여 정도 } \\
\text { - 훈련원에다한 인식정도 } \\
\text { - 양국 간 우호관계(외교, 경 제적 효과겸제사회적 공헌도) }\end{array}$ \\
\hline $\begin{array}{l}\text { 지속가능성 } \\
\text { (Sustainability) }\end{array}$ & $\begin{array}{l}\text { - 훈련원 운염의 자립발전섬 } \\
\text { - 시설, 기자재 보수 관리 딫 운염 능력 } \\
\text { - 기술이전 및 기술의 자립 발전섬(보수 관리) }\end{array}$ \\
\hline
\end{tabular}




\section{III. 평가 결과}

\section{1. 타당성}

\section{가. 수원국의 수요 및 정책과의 연관성}

과데말라는 중미 국가 총 GDP의 약 $1 / 3$ 을 차지하는 중미 최대 경제 국가이나, 전체 노동인구의 절반 이상 이 농업, 읽업 및 어업에 종사하고 있으녀, 사탕수수, 커피, 바나나 등 농산물이 과테밀라 전체 수출의 약 $60 \%$ 를 차지하는 등 전통적으로 농업이 국가 경제횔동 의 는간을 이루고 있다. 과테말라는 전체 인구 중 $20 \%$ 를 점유하는 극빈층이 전체 소득의 $1.9 \%$ 만을 차시하고 있어, 저·중소득 국가 중 브라질과 파키스탄에 이어 가장 높은 소득불균형 현상을 보이고 있으며, 중남미 국가 중 아이티(Haiti) 다음으로 가장 낮은 취학률을 기록하고 있어 경제 및 사회 구조가 전반적으로 취약 하다. 그리고 정규직 기준 실업률이 약 $40 \%$ 에 달해 사 회불안 오인이 되고 있는 한편 경제발전의 근본적인 저해요인으로 작용하고 있다.

따라서 동 기술교육훈련원 건립 사업은 과테말라가 추 진하고 있는 경제구조 다변화에 필요한 공업기술 인력 을 양성하여 괴테말라의 경제발전에 기여함은 물론, 과테말라 중 - 저소득 계층이 정상적인 직업에 의한 생 활을 영위케 함으로써 사회 안정에도 기여할 수 있는 사업이다.
이에 한국 정부는 KOICA를 통해 2003년부터 2004년 까지 Zacapa 시에 기술교욱훈련원을 설립하고 4 개 공 과(사동차정비, 용접배관, 이미용, 제과제빵)의 관련 기자재 지원과 연수생 초청, 조사 및 사업관리를 실시 하였다. 지역신업과 인력수요의 특성, 그리고 아국 지 원의 용이성을 고려할 때 타당성이 높은 공과가 신 설· 운영되고 있는 것으로 평가된다.

\section{나. 사업계획 수립의 적절성}

\section{1) 사업계획상 사업방식의 적절성}

과테밀라 징부의 요청 내용과 사전조사 결과를 토대로 수립한 사업추진 계획은 적절한 것으로 펑가된다. 사 업 추진을 위한 사전조사는 물론 아울러 양국 간 분담 사항, 헙의의사록 교한 등을 함께 수행하였다.

과테만라는 생산기계, 전기, 가전수리, 용접 직종에 대 한 지원을 요청하였는데 향후 정상적인 운영을 위한 가능성을 판단한 결과 ${ }^{1}$, 지원사업의 종료 후에도 시속 적으로 틋성화하여, 훈련에 적합한 질과 양의 장비 공 급으로 질적 향상 및 가시적인 지원 효과와 더불어 수 읙사업을 통해 자립운영의 효과를 기대할 수 있는 공 과로 확정하였다. 현시에 건축, 기사재 시원, 전문가 파견, 연수생 초청 등도 과테말라의 요청 사항에 내하 여 예산 및 현지 사정, 내용 등을 고려하여 합리적으루 조정된 것으로 펑가된다.

1)Zacapa 지역 주변 도시의 산업시설, INTECAP의 훈련시설에 대한 지원나역, 자립기반 화보 가능성, 인적자원의 질, 교사의 능력 등에 대한 조사를 실시하 였다. 
사업실시 계획 및 그 방식은 과테말라의 요구시항을 철 저히 분석하여 반영하고 또 조정 과정을 퉁하여 합리적 인 계획을 수립하였다. 그리고 $\mathrm{KOICA}$ 의 수정 제안에 과테말라 측도 대부분 동의하여 추진되었으며, 사전 타 당성 조사 및 신시협의 전문가들의 권고 사항도 대부분 수용-되어 사업 수행이 원만하게 진행되었다.

\section{2) 사업계획 수립 시 리스크와 이해관계자 분석}

사업 추진계획 수립 시 지원 항목볼 장단점을 분석하 고 기본방향을 제시하는 것은 중요하다. 사업 계획 수 립 시 주요 내용을 보면 아측은 건축예산 50 만 달러 지 원을 통해 훈련원 건물을 시공하고 입체 신징 및 4 개 공과 훈련기자재를 지원하며, 자동차정비와 용접공과 에 대해 연수생을 초청하도록 에정되어 있다. 과테말 라는 초과하는 건축비용 발생 시 초과비용을 부닩하 며, 기자재 지원 관련 세금 및 운송, 보관비용 등의 사 항을 부담한다. 특히 INTECAP 및 SEGEPLAN과의 업무 협의와 Zacapa 시 당국은 건축 관련 인히가 및 토목 관련 문제해결에 전폭적인 협조를 약속하였다.

특히 긴축 사업의 호율적인 진행 및 전문적이고 체계 적인 관리가 필요한데 이를 위해 선정 업체가 설계단 계바-터 준공 이후 사후 관리까치 일관성 있게 전 과정 을 모니터링하고 업체간, 업체와 $\mathrm{KOICA}$ 간 갈등을 조 율할 수 있도록 하였다.

또한 훈련원 지원 및 공과 개설 등에 대해 전반적으로 그 타당성을 인정하고 있으녀 만족도가 높은 것으로 나타났다. 그러나 일부 의견에서 훈련교사의 역량 강
화를 위한 방안 및 실습실 및 강의실, 훈련 장비와 실 습 도구 및 재료에 대한 충분한 확보가 필요한 것으로 나타났다.

\section{3) 사업 대상지 선정의 타당성}

과테말라 정분는 이리 정부의 시원으로 '93 '99년간 설립되어 성공적으로 운영되고 있는 3 개 직업훈련원 을 높게 평가하며 INTECAP을 통해 과테말라시 동북 부에 위치한 교통의 요충지인 7acapa 주에 기술교-육 훈련원 건립사업을 아국에 요청해왔다. 이에 조사단은 과테말라 측에 Zacapa 시내에 훈련원 부지를 선정해 줄 것을 요구했고, 과테밀라측은 이를 원칙직으로 수 용했다. 사업대상지역은 많은 산업시설이 위치하여 직 업훈련수요가 많은 것으로 판단되며 정부기관과 인접 해있고 전기, 상하수도 등 인프라 구축이 용이하녀 도 로가 위치하여 훈련 생의 집근성이 꽆아 훈련 원 건추에 매우 적합한 것으로 평가된다.

\section{2. 효과성}

\section{가. 사업 목표(목적)의 달성도}

본 사업은 기술교육훈련을 통한 숙련 기술인력 양성 및 공급으로 과톄말라 Zacapa 지역 사회 및 국가 경제 반전에 기여힘을 목적으루 수행되었다. 사업목표 달성 여부 검토 및 펑가를 위해서는 성과 관리 측정지표 설 정이 필요하다. 본 사업에서는 사업계획 대비 추진 실 적의 단순한 산출지표만으로 측정할 수밖에 없는 한계 가 있어 제한이 따른다. 일반적으로 직업훈련기관 및 
프로그램 펑가에서는 훈련기관 경영, 시설 및 장비여 건, 훈련교사 여건, 훈련생 관리 등 훈련기관 부분과 훈련과정 개발 및 운영, 학습평가, 훈련실적, 만족도 등 훈련과정 운영 부분으로 나누어 지표를 설정한다. 한 - 과테만라 기술교육훈련원은 대부분의 지표에시 우수한 수준에 있다고 할 수 있다. 향후 목표 달성도에 대한 평가를 위하여 정량적 성과시표를 사전에 선정하 고, 이를 사후적으로 비교 분석할 수 있는 틀을 나련할 필요가 있다.

\section{1) 공과 설치 및 운영 현황(표1 참조)}

\section{나. 사업 활동의 목표달성 기여도}

본 사업은 당초 계획에 의거하여 기술교-육훈련원이 신축되고 전반적으로 관련 기자재가 목적에 맞게 설 치 · 활용되고 있음을 확인하였고 훈련성과의 측면에 서 각 공과과정별로 수립된 연간 훈련생 훈련 목표를 대부분 충실히 달성해 가고 있으며, 특히 일부 훈련과 정(제과제빵, 사동차정비)의 경-이 높은 훈련실적을 나 타내었다.

〈표 1〉설치공과 및 학생정원

\begin{tabular}{|c|c|c|c|c|}
\hline 직 중 & 인 원 & 기 간 & 배츨인원/년 & 비 포 \\
\hline 자동차점비 & 20몀 & 1년 & 80몀 & 점규 20몀, 단기 60명 \\
\hline 용접 & 20명 & 1년 & 80명 & \\
\hline 제과 · 제빰 & 20명 & 1년 & 80명 & \\
\hline 이·미용 & 20명 & 1년 & 80명 & \\
\hline 계 & 80명 & - & 320 명 & \\
\hline
\end{tabular}

취업 및 고용 성과와 관련해서는 훈련원 관계자와의 면담을 통해 지역 사회에 효과적으로 인력이 배출 - 활 용되고 있다는 답변을 받았시만 일부 주요기업(코카콜 라 공장 등) 취업과 창업(제과짐) 사레를 파악하는 징 도 이외에 전체 훈련 이수생에 대한 체계적인 취업 지 도 · 알선 · 실태 파악은 제대로 이루어지지 않고 있는 것으로 나타났다. 이너한 취업관련 시스템은 향후 INTECAP 차원에서 체계적으로 구축할 필요가 있는 것으로 판단된다.

\section{다. 사업의 목표 집단에 대한 기여도}

\section{1) 수혜국(과테말라) 차원}

훈련원 건축이나 장비 지원도 중요하지만 우리나라의 직업훈련의 노하우를 인럭 파견, 초청 연수 등의 방법 으로 전수함으로써 과테밀라의 지ㅇㅣㅣㅂ훈련 관련 징책 수 립 및 운영, 전략에 대한 기츠를 제공하였다고 볼 수 있다. 또한 현재 대미국 중심의 통상 관계에서 탈피하 여 $\mathrm{EU}$, 아시아와의 관계 증진을 모색하고 있는 과테말 라와 우리나라가 직업훈련분야 협력을 통해 양국 간

※ 공과 : 4 게 공과, 지원부서 : 2 게과 
우호협력증진이 강화되는데 기여한 것으로 펑가할 수 있다.

\section{2) 사회차원}

본 사업은 미취업 청소년 및 재교-욱이 필요한 는로자 를 대상으로 기술 인력을 양성하여 시역사회에 공급하 는 역할을 충분히 수행함으로써 청년실업 해소 및 사 회 취약계층의 인정적 기반 마련, 나아가 지역 경제의 활성화라는 사회적 차원에서도 큰 기여를 한 것으로 평가된다.

\section{3) 설문조사}

한국 훈련원의 교-육과정에 대한 만족도 조사에서 훈련 교사의 $66.7 \%$ 가 만족한다.'라고 응답했고 $33.3 \%$ 가 '만조ㅎㅏㅏㅈㅣ 읺는다.' 라고 응답하였다. 만조한다.' 고 답 한 교사의 경우 '비록 짧은 시간이었지만 타국의 문화 와 기술을 습득할 수 있었기 때문에 좋은 경험이었다.' 고 답했고 '플라즈마 용접 방식과 로놋을 이용한 사동 용접 등 첨단 기술을 배울 수 있어 좋았다.' 는 기타 의 견도 있었다. 그러나 만족하지 않는다.' 라고 응답한 경우도 있었다. 만족하지 않는다.'라고 응답한 훈련 교사 대부분은 '훈련기간이 짧고 훈련기술수준이 너 무 낮다.'라고 답했다. 이를 동해 한국 훈련원 교육과 정에 대한 개선사항을 재고할 필요가 있을 것이다.

훈련원이 지역 산업 계에서 필요로 하는 양질의 인력공 급에 성공적 이였느냐는 질문에 '그렇다.' 라고 응답한 훈련 생의 비율이 $98 \%$ 로 매우 높게 나타났다. 이는 훈
련원이 효과적으로 운영되고 있고 그에 따른 목적 달 성도도 높다는 것을 시사한다.

\section{3. 효율성}

\section{가. 수원 행정 체계}

과테말라의 기술교육훈련 지원 사업에 내한 행정체계 는 원조 총괄기관으로 국가경제기획청(SEGEPLAN: Secretaria de Planification y Programacion)이 주관하고 국형 전문직업훈련기관인 직업훈련 밎 생산 성 기술연구원(INTECAP: Instituto Tecnico de Capacitacion y Producividad)이 기술훈련 사업을 전 담하여 실시한다.

본 사업은 초기부지선정에서부터 설치운영에 관한 협 의 의사로 $(\mathrm{R} / \mathrm{D})$ 체결 등 $\mathrm{KOICA}$ 현지사무소와 동 사업 운영주체인 INTECAP과의 유기적인 업무협조를 통해 사업 진행이 일관성 있게 이루어진 것으로 평가되며, 기술교육훈련기관 운영 차원에서도 INTECAP 본보가 매년 개발 - 보급하는 표준화된 교윢훈련과징이 각 공 과별로 실시되고 있으며, 전체적인 예산 및 직원관리 도 INTFCAP 본부 관리 하에 체계적으로 이루어지고 있다.

\section{나. KOICA 사업체계}

$\mathrm{KOTCA}$ 는 일련의 사업 수행 방식에 따라 본 사업을 추 진했으녀 관련 부서 및 현지 사무소간 긴밀한 업무 협 조 및 지원으로 사업 수행은 원활하게 진행된 것으로 
펑가된다. 또한 현지 사무소와 본 사업의 괴데말라 정 부 측 주관기관인 INTECAP과의 사업수행도 원활한 것으로 평가된다.

\section{다. 사업의 달성도 및 완성도}

\section{1) 사업계획 대비 달성도}

본 사업은 당초 사업 계획에 따라 모든 사항이 이루이 졌으며, 예산문제나 기술적인 문제로 사업이 변경 또 는 조정되시는 않았다. 건축비 난가인상으로 건축입찰 에 어려움을 겪었으나, 최종 건축계약시 유러한 가격 으로 계약이 성사되어 큰 장애요소는 없있다. 이에 사 업계획 대비 달성도는 매우 높은 것으로 평가되며, 사 업 전반적으로 원간하게 추진된 것으로 분석 된다.

\section{2) 시설물의 완성도 및 적합도}

본 사업의 추진단계에서 철는 값 인상으로 어려옴을 겪었으나 원하는 방향으로 건축계약이 성사되었고 시 공도 대체적으로 잘 이루어져 사업목표를 달성한 것으 로 평가된다. 수원국 측도 긴축에산을 전감하기 위해 INTFCAP 사상 치음으로 수주에 의한 시공을 하지 않 고 직접공사를 실시하여 다소 어녀움이 있었으나 결과 적으로 수원국 측도 저렴한 비용으로 성공적인 건축을 시공하었으며, 공사과정에서 $\mathrm{KOICA} \mathrm{CM}$ 측과도 원횔 한 업무협조가 이루어져 전체적으로 성공적인 시공이 이루어진 것으로 평가된다.

향후 유사 프로젝트를 수행할 때 건물 설계 시 현지 실
정에 맞고 향후 관리가 용이하도록 제반시항을 고려하 여 작성해야 하며, 사업운영 주체인 수원국의 의견을 많이 반영함과 동시에 우리나라의 선진적인 기술이전 이 반영되어야 하는 부분이 있으므로 양국 간 의견조 율이 수빈되이야 할 것이다.

\section{3) 사업에 사용된 기술과 파견 인력 및 연수인력의 적합성}

기술교육훈련원의 각 공과별 장비운영, 교수학습 방법 밎 훈련원 운영 전반에 대한 자문할동을 위해 전문가 파견이 이루어졌다. 이는 우러나라의 각 직종별로 축 직된 신진기술을 전수함으로써 향후 훈련원 자체 운영 에 대비한 교육으로 이루어졌고 만족도도 매우 높은 것으로 나타났다.

훈련교사를 대상으로 실시된 국내초청 연수는 다양한 프로그램으로 실시되어 그 호과는 매우 큰 것으로 평 가된다. 일부 개선되어야 할 사항으로 연수 기간의 연 장 및 최신기술 전수 등의 의견이 제기 된 바, 연수 기 간은 연수생들의 과징이해에 필요한 충분한 시간을 감 인하여 책정되어야 할 것이다. 향후 연수생 선반 시 연 수 효과 및 지속성을 고려하여 연수과정에 부합하는 적정 인력을 선발하여 교육하는 것이 필요하고, 체계 적이고 효과적인 연수를 위해 분야별, 연수기간벌 교 육교재 개반이 이루이져야 하며, 연수기관간 경쟁력 유도를 위해 신규연수기관을 계속적으로 발굴 및 육성 해 나가야 한다.

\section{4) 사업 관리 체계의 효율성}


사업의 효율적인 운영을 위하여 KOICA 현지 사무소 등 우리측 관계기관과 과테말라 기술교육훈련청 (INTECAP), Zacapa 주정부 밎 현시 기술교육훈련원 등이 유기적인 협력관계를 유지하며 사업을 추진하였 다. 그 과정에서 훈련원 긴립과 운영을 위한 다양한 기 관 및 수요자들의 수요를 파악하고 이를 반영한 것으 로 평가된다. 이더한 모니터링 과정을 거쳐 집행과정 의 투명성과 효율성을 확보한 것으로 보이녀, 여할 분 담 또한 원횔하게 이루이진 것으로 분석된다.

\section{5) 사업 활동의 계획대로 이행 여부}

기술교윻훈련 지원 사입은 국내 조건보다는 수원국 현 지 상황에 따라 계획과 달리 진행될 소지가 높은 특수 성을 가지고 있다. 본 사업은 대부분의 사업들이 당초 계획대로 집행된 것으로 펑가되녀, 예산 집행에 있어 서도 사전 조사 및 현지 실징에 대한 징밀한 분석으로 초기 예산 편성에 따라 효율적인 집행이기능하였다.

\section{라. 설문조사}

한국에서 파견한 전문가에 대한 민족도를 조사한 결 과, 다섯 항목 모두 보통 이상의 만족도를 니타내었다. 기계 작동 유시에 대한 전문성과 훈련프로그램 관리에 대한 전문성, 훈련원 운영의 행정 및 재정적 지원확보 노력에 대한 항목에서 '민족힌다.' 가 $66.7 \%$ 로 비교적 높은 만족도를 나타내었으며, 특히 교재기발에 대한 전문성 항목에서는 '매우 만족한다.' 가 $66.7 \%$ 를 나타 내었다. 또한 훈련프로그램 관러에 내한 열정 항목에 서는 '매우 만족한다.', '만족한다.', '보통이다.' 가 각
각 $33.3 \%$ 로 고른 분포를 니타내었다.

훈련원 과정을 이수한 후에 취업할 가능성에 대해 질 문한 결과, '취업할 것이다.' 라고 응답한 경우가 $67.7 \%$, ‘ㅊㅓㅓㅂㅂㅇㅣ 매우 어려울 것이다.' 가 $9.1 \%$, ‘취업 못 할 것이다.' 가 $1.0 \%$ 를 차지함으로써 취업가능성에 대한 전망은 상당히 긍정 적인 것으로 보인다. 또한 기 타 의견이 $21.2 \%$ 를 차지하였는데 응답자 모두가 훈련 과정을 이수한 후에 ‘본인 사업을 하겠다.' 라고 응답 하였다.

\section{4. 파급효과}

\section{가. 사업의 상위목표(Overall goal)달성 가능 성 및 긍정적 효과}

동 사입은 현재 미국 중심의 통상 관계에서 달피하여 $\mathrm{EU}$, 아시아와의 관계 증진을 모색하고 있는 과테말라 와의 국가 간 협력관계 증진에 중요한 시례가 될 것으 로 평가된다. 중미 내 가장 큰 인구대국인 과테말라는 미국-중미 자유무역 협정 (DR-CAFTA)의 진행에 따라 향후 지속적인 외국기업의 투자 유치와 힘께 중미 지 역 내 경제중심 역할을 하기 위해 노력하고 있고 이에 따나 경제발전에 필요한 인력 양성 수요는 급속히 증 내할 것으로 예측되녀 과테말라 동부지역의 인럭양성 을 지원하기 위해 선립된 Zacapa 기술교육훈련원의 수요와 활용 가치 또한 지속적으로 증대될 것으로 보 인다.

뜨한 부수적 효과로서 기술교육훈련기관에 지원된 한 
국의 첨단장비와 기술 그리고 전문가 역랑이 높게 인 정받아 향후 훈련 생 배출을 통한 과테말라 내 한국 수 출품의 인시도 향상에도 기여할 것으로 판단된다.

\section{나. 사업의 역량개발 및 제도강화 기여도}

과테말라는 기술인력 양성을 통해 시역사회 및 국가의 산업발전을 도모해야 하는 단계에 있으므로 숙련기술 인력을 양성하는 본 훈련원에 대한 지원은 지속적으로 큰 효과를 거둘 수 있는 사업이다. 본 훈련원 지원 사 업은 향후 양국 간의 우호관계 증진은 물론 지속적인 경제협럭의 중요한 수단으로 기능할 것으로 예상되녀 특히 과테밀라의 취약계층에 대한 훈련기회 제공 및 취업가능성 제고에 기여하고 있다.

\section{5. 지속가능성}

\section{가. 시설, 장비관리 및 유지 가능성}

본사업에 시원된 시설과장비에 대해 구체적으로 사후 관리 계획을 수립하고 있지는 않으나 향후 수원 국이 자 체적으로 시선과장비 관리 및 유지를 지속적으로 수행 하도록하기 위해 우선적으로 추가 지원에 대한 타당성 을 검토하고 시원하는 방안이 필요한 것으로 보인다. 또한 수원국은 시설 및 장비 관리를 위한 예산과 인럭 투입 등 체계적인 관리 계획을 수립할 필요가 있다.

\section{나. 사업의 자립발전성}

본 사업의 수혜기관인 INTECAP은 전국 총 21개 기술
교육훈련기관을 총괄하는 정부기관으로 전체적인 관 리업무를 담당하고 있다. 또한 INTECAP은 중미 다른 나라의 기술교육훈련기관인 INA (코스타리카), INATEC (니콰라과) 등과 깉이 기업체 수읙의 일징비 율(1\%)을 기술교육훈련사업 으루 사용할 수 있어, 기술 교-육훈련 소요 재원의 지속적이고 안정적인 확보가 가 능한 여건이 마련되어 있다. 이와 함께 INTECAP 운 영을 결정하는 이사회를 산업계(산업 · 상업 · 은행 · 농업연맹 대표-), 노동계(3개 전국노동조합 대표), 정부 (노동부 - 경제부 - 대외기술협력청)가 공동으로 구 성·운병함으로써 안정적면서도 효과적인 정책운형이 가능한 바, 본 사업의 자립 발전 가능성은 높은 것으로 보인다.

\section{다. 설문조사 결과}

훈련원 활동을 지소하기 위한 자원의 충분싱에 대한 질문에서 '충분하다.라고 응답한 비율이 $74 \%$ 로 나타 나 훈련원 운영에 필요한 대부분의 요소가 양호한 것 으로 보인다. 그러나 충분하시 않다면 추가로 필요한 요소가 무잇인가에 대한 질문에서 훈련장비가 $33.3 \%$, 시설이 $29.6 \%$, 기타의견으로 실습재료가 핀오하다는 의견이 $14.8 \%$ 로 니타나 이에 대한 제고 필요성이 있는 것을 알 수 있다.

훈련 직종의 미래 전망에 대한 진문에서 훈련생의 $85.9 \%$ 가 '전망 있다.' 라고 응답하였는데 이를 통해 훈 련원이 개설한 공과 분야의 전망에 대해 매우 긍정적 인 것을 알 수 있다. 


\section{6. 추가 지원 관련}

\section{가. 훈련원의 추가지원 의견}

훈련교시의 경우, 훈련원 시설 및 훈련 장비와 도구, 훈련과정 등 운영 전반에 관해 대 부분 만족한다는 의 견을 보였다. 그러나 일부 의견으로 프로그램 운영을 위한 지원이 부족하다고 답하였는데, 현재 개설 중인 공과 외에 다른 분야의 기설을 희망하는 의견도 있었 다. 또한 이론 수업을 위한 강의실 확보 및 충분한 실 늡실과 훈련 기자재의 지원이 필요하다는 의견이 있 었다.

훈련생의 경우도 마찬가지로 훈련 원의 훈련과정 전반 에 필요한 물적 및 인적 자원에 대해 전반적으로 만족 도가 높은 것으로 나타났다. 그러나 기타 의견으로 훈 련 신습을 위한 충분한 도구 및 재로 등의 지원이 더욱 보완되어야함을 강조하였고 우수학생을 대상으로 한 국에서의 연수기회 제공, 장학금 제도 마련, 정규 훈련 과정 외에 추가적인 과외활동에 대한 요청, 훈련원 나 편의시설 마련 등 시설 운영에 대한 지원의 필오성을 나타냈다.

\section{나. 사후관리 지원 타당성 검토}

과테말라의 국가적 치원의 과제인 훈련원을 통한 기술 인력 양성은 지속적으로 관리될 폴요가 있다. 이에 훈 련원의 안정적이고 효과적인 운영을 위해서는 반드시 추가 지원이 푈요한 것으로 판단된다. 이러한 사후 관 리 지원을 고려할 때 인부에 국한하지 만고 훈련원이
안고 있는 기존의 문제점을 해소할 수 있는 전면적인 검토와 지원이 이루어져야 할 것이다.

현재 지원되는 시설 및 장비 등은 훈련교사와 훈련생 모두에게 민족스러운 수준이나 훈련 기자재의 충분한 지원이 필요하다는 일부 의견이 있으며, 훈련원에 지 원한 기사재 일비-의 경우 서가품이 공급되어 성능이 미흡하고 불만족스러우므로 비독 양국 간 헙의의사록 에는 프로젝트 종료 후 부품 및 소므품 공급은 수원국 측 부담사항으로 명시하고 있으나 현지 시장에서 구입 할 수 없는 비품은 장비 조달업체에서 상업베이스로 공급하도록 하는 방안을 강구할 필요가 있다. 이에 내 한 사후관리 지원의 타당성 검토와 더불어 지속직으로 훈련 기술이 전수되고 자체 인력으로 훈련 원이 운영되 기 위해서는 재정 및 운영 전반 사항에 대한 추가 지원 이 필요하다고 본다.

\section{7. 기타}

\section{가. 후속사업 추진 검토}

동 훈련원이 시내 중심가에 위치하고 훈련원 맞은편에 $7 a c a p a$ 주정부 건물이 신축 중이므로, 지리적 위치는 양호한 편이나 대중교통이 발달되어 있시 않는 것을 고려해 훈련원 공용버스(약 30 인승)를 제공할 필요가 있다. 통근비스가 제공되면 흭생 및 훈련교사에게 매 우 유용하게 활용될 수 있다고 판단되며, 우리니라 자 동차 산업의 인지도 향상과 $\mathrm{KOICA}$ 를 통한 양자협력 사업에 내한 홍보효과도 클 것으로 판단된다. 


\section{나. 타 사업과의 연계}

아구 업체를 비롯한 선진기업들의 Zacapa 인근 지여 진출에 대비하여 봉제 및 냉동공조공과의 추가 설치를 요청하고 있으므로 공식 사업요청이 있을 시에 본 사 업과 연계하여 사업 효과 및 완성도 제고 차원에서 긍 정적으로 검토할 필요가 있다고본다.

\section{IV. 결론 및 교훈}

\section{1. 목표달성도 및 효과}

7acapa 주 및 인근 지역 취업희망 청소년과 재교육이 필요한 근로사를 대상으로, 기술인력 양성을 지원하여 지여사회와 국가경제 발전에 기여한다는 사업목표로 진행된 본 사입은 소기의 목표를 충분히 달성한 것으 로 평가된다. 졸업 후 훈련생의 기술 수준이나 취업에 대한 전망이 높은 것으로 나타났고, 특히 지역 산업계 에서 필요로 하는 인려을 공급함으로써, 지여 산업 수 요에 부합하는 훈련과정이라는 평가는 매우 높은 효과 성을 보여준다. 뚜한 지원된 대부분의 시설과 장비가 훈련에 적합하게 활용되었고 향후 실습 기자재에 대한 추가 시원이 보완된다면 보다 완성도 높은 효과를 기 대할 수 있을 것이며, 주재국 직업훈련원 운영의 훌륭 한 모델이될 수 있을 것이다.

\section{2. 자립발전 전망}

수원국의 경제반전 및 인적자원 개반에 대한 적극적인
의지, 기술교육훈련 기관을 총괄하는 정부기관인 INTECAP의 정책과 관리 능력은 효과적인 훈련원 운 영을 시원하여 1 자립발전의 가능성을 높이고, 기업 체 수익의 일정 비율 $(1 \%)$ 을 기술교윢훈련 사업으로 사 용할 수 있는 운영 재원의 안정적인 확보 또한 재정적 측면에서의 자립발전가능성을 높일 것으로 평가된다. 향후 선진적인 직업훈련기관으로서의 체계를 갖주기 위해서 KOICA 측의 사후관러 지원이 필요하녀 수원 국측도 주인의식을 가지고 이를 계속 반전시켜 나가야 할 것이다.

\section{3. 효과제고 요인 분석}

호과 제고 요인으로는 4가지로 분석할 수 있다. 먼저, 시장 수요에 부응하는 공과 개설 및 운영이다. 과테말 라 정부가 추진하는 경제발전 정책의 일환으로 변화하 는 기술교육 수요에 대처하기 위해 아국의 비교우위가 있는 자동차정비, 용접 등 신기순 분야 기능인력 양성 을 추진한 점, 과테말라 서민층의 소규모 창업에 실질 적으로 도움이 되는 제방 및 미용 공과를 선정하여 지 원하는 등, 동 사업은 대내외적인 환경을 고려하여 적 절한 계획수립과 집행이 이루어진 것으로 판단된다.

둘째는 적합한 시설 장비 공급이다. 취업 후 바로 현 장에서 활용할 수 있는 기능을 훈련하고, 이에 부합하 는 첨단 시설 장비를 지원하여 효과가 크게 나타나고 있다.

셋째는 훈련원 및 훈련교사의 적극적 찬여다. 효율적 인 훈련원 운영, 체계적으로 지원되는 적합한 시설, 첨 
단 장비 및 다양한 시청각 자료를 활용한 교육과 역량 있는 교사들의 열정적 참여라는 최적의 상태로 훈련원 이 운영되고 있는 것으로 평가된다.

마지막으로 연수생 초청을 들 수 있다. 지원 장비에 대 한 유지보수 및 실습지도 방법, 개설과정의 운영 및 교 수시도 방법, 공과 운영관리기법 등 관련분야의 기술 및 노하우를 전수하고 신기술을 습득할 수 있는 기회 를 제공함으로씨 향후 훈련 원을 운영할 인재를 육성하 는데 기여하는 것으로 평가된다.

\section{4. 효과저해 요인 분석}

효과저해 요인은 3 가지로 분석 할 수 있다.

첫째, 실습기자재 지원 강화이다. 천단 기술 장비 및 실습기자재 지원에 대해 대부분의 훈련교사 및 훈련샘 들의 만족도는 매우 놇은 것으로 나타나지만 신습도구 및 실습재료 부족으로 충분한 훈련기술 습득의 기회가 제한되는 바, 이에 대한 시원이 필요한 것으로 보인다.

둘째, 훈련원 시설에 대한 지원 강화이다. 훈련원 시설 및 운영에 대한 만족도는 전반적으로 높은 것으로 니 타나시만 이론수업을 위한 강의실 및 충분한 실습실 확보, 운동장과 같은 교과과정 외 추가활동 프로그램 을 위한 공간 획보 및 훈련 원내 식당 운영 등의 편의시 설에 대한 지원 요청도 있는 것으로 나타나 이에 대한 타당성 검토가 이루어저야 할 것이다.

셋째, 파견 전문가의 역할 제고이다. 파견될 전문 업체
를 선정하여 지원기자재 리스트 작성 및 현지 여건조 사, 장비설치 및 운용교육 등을 실시하였으나, 사업추 진과정에서 파견업체로서의 책임감, 전문성, 능동적 자세가 부조하여 효율적인 사업추진에 애로가 있었으 므로 향후 사업추진과정을 보다 효과적으로 모니터링 하는 시스템을 구축하고 이를 평가, 관리하는 노력이 필요하다.

본 사업은 당초 목표대로 지원되어 원횔하게 운영되고 있는 것으로 평가할 수 있다. 초기 부지선정에서부터 건축 시공 및 감리, 기사재 공여 및 설치운형에 관한 협의의사독(R/D) 체결 등 전반적으로 일관성 있게 사 업을 수행하였고 $\mathrm{KOICA}$ 현지사무소와 동 사업 운영 주체인 기술교-육훈련청(TNTFCAP)과의 유기적인 업 무 협조체제가 바탕이 되었다. 또한 타 원조 공여국에 비해 상대적으로 적은 예산(비화 120 만 달러 상당)으 로 수원국의 미래 산업수요와 지역 경제의 싱장 동력을 제공할 수 있는 이정표를 마련하였다는 점에서, 향후 개발도상국에 직업훈련사업을 수행하는데 있어 모번 사례로 원용될 수 있을 것으로 판단된다.

\section{$\mathrm{V}$. 시사점}

\section{1. 사업계획 단계}

과테말라의 사회경제적 수요와 현지 상황을 충분히 고 려하고 반영하어 사업 목표를 설정해야 당초 계획한 목 적을 달성할 수 있다. 적합한 훈련직종 선정, 훈련수준 및 이에 따른 교과과정과 교재개빌, 훈련시설과 장비 
의 수준, 규모 및 배치 등에 대한 사전 검토가 필요하 며, 양국간 합의된 사항의 숙지, 물적 - 인적자원 등의 투입요소가 일정에 맞게 추진되도록 할 필요가 있다. 연수생 초청, 전문가 파견 등 인적자원개빌 및 기술전 수 등 소프트웨어 측면은 개반도상국이 직업훈련 분야 의 지원을 퉁해 지속적인 국가발전을 도모할 수 있도 록 하는데 중요한 요소이므로 충분한 시간과 검토가 필요하다.

\section{2. 사업집행 단계}

\section{가. 시설 및 장비 지원}

훈련원 건축은 현지의 건설 관행과 더불어 기후 특성 을 감안하여 계약단계에서부터 면밀하게 검토해야 한 다. 훈련장비는 훈련에 쉽게 활용할 수 있을 뿐 아니라 현지에 직합하고 유지, 보수 및 관리가 용이한 제품이 선정 되어야 하므로 지원 장비의 선정에서도 현지 상황 을 충분히 고려해야 한다. 반드시 장비의 성능과 내구 성이 뛰어난 제품을 시원 해야 하므로 국내에서 품질을 인정받은 제품을 선정해야 한다. 뜨한 동일하거나 유 시한 수준의 장비가 현지에 있다면, 현지 제품을 구 입 설치할 수 있도록 하거나 그 비중을 늘릴 수 있도 록 하는 것이 바람직하다. 장비 활용 시 버수적으로 실 습재료 구입비도 일정기간 훈련원에 지원할 필요가 있 으나 원횔한 훈련원 운영을 위해서는 신습재라 비용은 자체 조달할 수 있도록 훈련원을 운영해야 한다. 훈련 장비의 원활한 작동과 현지 부품 활용을 통한 보수를 위해서는 취급설명서와 내뉴얼이 과테말라 현지어로 제공되어야한다.

\section{나. 국내초청 연수}

국내초청 연수의 경우, 일반적인 교육수준에 그치고 있어 현지 필요성을 고려한 연수 내용 등 보다 활용도 높은 교육이 이루어져야 할 것이다. 또한 관련 분야의 신기술 및 노하우를 습득하고 개설과정의 운영 및 교 수시도 방법에 대한 교육 뿐 아니라 일리나라의 경제 및 사회, 문화 경험을 통해 연수 효과를 극대화하고 나 아가 양국간 교류증진의 기반을 마련하는 기회가 되어 야할 것이다.

\section{다. 전문가 파견}

전문가 파견은 과테말라 현지 사정을 충분히 고려하여 이루어셔야 하므로 이를 고려하여 사전에 파견시기, 기간, 분야, 여할 등을 검토해야 한다. 전문가는 시설 및 장비가 현지에 도착, 설치되기 전에 파견되어야 하 고 훈련원에 서 자체적으로 운영이 용이하도록 장비의 검수, 배치, 설치 등을 주도적으로 수행해야 한다. 또 한 설치된 장비를 훈련교사 및 훈련생들이 쉽게 활용 할 수 있도록 충분한교육이 이루어져야 한다.

\section{3. 사업종료 및 사후관리 단계}

사입종료 후에도 지원된 훈련시설 및 장비가 제대로 운영 및 횔용되고 있는지에 대한 지속적이고 주기적 인 점검과 모니터링이 이루어져야 한다. 이를 위한 체계적인 사후관리 시스템의 도입이 필요하며, 훈련 직종별 신기술 정보 및 활용 방법 제공, 문제해걸 방 안 제공은 문론 안정적인 재정확버와 기관 운영의 
노하우 제공을 위한 노력을 지속적으로 할 필요가 있다.

\section{VI. 정책 제언}

\section{KOICA에 대한 제언}

\section{가. $\mathrm{PMC}$ 업체 관리 강화}

동 사업 중료평가에서도 시적된 바와 같이 $\mathrm{KOICA}$ 를 대신하여 지원 사업을 수행하는 PMC 업체에 대한 관 리를 강화할 필요가 있다. 먼저, 우수기자재 공급을 통 한 국가이미지와 브랜드 향상을 위해서는 PMC 업체 와 계약 체결시, 명확한 가이드라인을 제시하고, 기자 재 하자발생시 소환(Recall)제도를 도입하여 운영할 푈요가 있다.

또한 전문가 파견 및 국내초청 연수와 같은 기술협력 에 있어서도 $\mathrm{KOICA}$ 차체적으로 사전 점검 기준과 절 차를 두어서 적절한 전문가인지 여부와 연수 과정의 기간과 내용이 적전한지를 사전에 관리할 필오가 있 다. 특히, 전문가 파견과 연수생 초청과 같은 분야는 한번 시행되면 기차재와 달리 다시 회녹이 어녀운 분 야로서 사전 전검이 더욱 중요한 분야라고 할 수 있다.

\section{나. 직업훈련 프로젝트 확대}

수원구인 과테말라의 1인당 GDP가 2,694달러(2006 년)인 중-저소득국이고 오랜 내전으로 인해 경제가
피폐하고 빈부격차가 삼한편이나 점차 치안상황이 호 전되어가고 있고, 중미 제일의 인구 대국으로서 $\mathrm{DR}$ $\mathrm{CAFTA}$ 체결에 관한 의회 비준 등 후속조치가 완결되 었고, 남미와 북미, 태평양과 카리브를 있는 지리적인 위치, 풍부한 노동력 등을 감안 할 때 앞으루 북미와 남미시장을 겨낭한 서방선진 기업과 우리기업의 진출 이 예상되므로 동 직업훈련원과 유사한 양사협력을 확 대, 발전 시켜 나갈 필요가 있다.

\section{2. 과테말라 정부에 대한 제언}

\section{가. 훈련원 운영을 위한 지원과 협력}

한국에서 지원한 직업훈련 기자재가 원활하게 운영될 수 있도록 과테말라 정부 차원의 에산 지원이 매우 필 요하다. 한국에서 지원한 기자재 일부는 훈련기관 차 원에서 중남미에서는 소모품을 구할 수 없는 경우가 있는데 이런 경우에는 과테말라 정부 차원에서 기자재 의 원활한 운영을 지원하여야 할 것이다. 과테말라 주 재 $\mathrm{KOICA}$ 사무소와 협의하여 $I$ 대책을 적극적으로 강구하여야 할 것이다.

\section{나. 훈련생 진로 및 취업지도 강화}

훈련목표에 맛세 훈련생을 충실히 훈련하는 것도 중요 하지만 이에 못지않게 중요한 것이 훈련생의 수준과 희망에 맞춘 적절한 진로 및 취업지도이다. 그러나 훈 련기관 면담조사 결과 훈련생의 훈련수료 후 취업 현 황에 내한 정확한 자료가 수집 · 구비되어 있지 않은 것으로 나타났다. 또한 훈련원 자체적으로 훈련공과별 
로 수료 후 취업이 가능한 기업체 현황에 대한 조사도 되어 있지 않았다.

따라서 과테밀라 징부에서는 훈련원에서 학생들에게 진로 및 취업지도를 할 수 있도록 지도 가이드를 개발 하여 제공하고 개별 훈련 원들이 소속 지역을 중심으로 취업 대상 기업체와의 정기적인 교류를 할 수 있도록 지도 · 독려해야할 것이다.

\section{다. 훈련교사의 직무능력향상 연수강화}

면담조사 걸과 훈련교사는 현재 근무여건에 대하여 대 체적으로 만좋하고 있으나, 일부 불만죽의 가장 큰 요 인으로 낮은 급여수준과 기술향상을 위한 기회 부족을 들고 있었다. 따라서 훈련교사의 직무능력 향상을 위
하여 괴데말라 국가 차원에서 연수 및 지원 제도를 마 련할 필요가 있다.

\section{라. 직업훈련과정 및 결과 평가 추진}

직업훈련 사업의 효율성을 높이기 위하여 직업훈련 과 정과 그 결과를 평가하여 이를 직업훈련에 피드백 할 수 있는 체제가 필요하다. INTECAP과 훈련원 관계자 면담 조사 결과, 전국적으로 체계적인 관리를 위해 노 력하고 있으나 훈련의 질과 결과에 대한 내용은 자세 히 파악하시 못하고 있는 것으로 파악되었다. 따라서 전국에 있는 직업훈련 시설 운영의 효율성, 교과과정 운영의 현장성, 훈련 결과 취입의 양과 질을 분석하고 이를 통해 니타난 문제점을 게선해 나캄으로 써 직업훈 련의 실호성을 높일 수 있을 것이다. 